\title{
Normalised flood losses in Europe: 1970-2006
}

\author{
J. I. Barredo \\ European Commission - Joint Research Centre, Institute for Environment and Sustainability, Via E. Fermi 2749, TP-261, \\ 21020 Ispra, Italy
}

Received: 24 April 2008 - Revised: 13 October 2008 - Accepted: 13 January 2009 - Published: 9 February 2009

\begin{abstract}
This paper presents an assessment of normalised flood losses in Europe for the period 1970-2006. Normalisation provides an estimate of the losses that would occur if the floods from the past take place under current societal conditions. Economic losses from floods are the result of both societal and climatological factors. Failing to adjust for time-variant socio-economic factors produces loss amounts that are not directly comparable over time, but rather show an ever-growing trend for purely socio-economic reasons. This study has used available information on flood losses from the Emergency Events Database (EM-DAT) and the Natural Hazards Assessment Network (NATHAN).

Following the conceptual approach of previous studies, we normalised flood losses by considering the effects of changes in population, wealth, and inflation at the country level. Furthermore, we removed inter-country price differences by adjusting the losses for purchasing power parities (PPP). We assessed normalised flood losses in 31 European countries. These include the member states of the European Union, Norway, Switzerland, Croatia, and the Former Yugoslav Republic of Macedonia.

Results show no detectable sign of human-induced climate change in normalised flood losses in Europe. The observed increase in the original flood losses is mostly driven by societal factors.
\end{abstract}

\section{Introduction}

Flood disasters are the result of both societal and climatological factors, hence several other drivers than climate must be considered for the assessment of flood-damage trends. Moreover, there is evidence that societal change and economic development are the principal factors responsible for

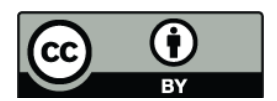

Correspondence to: J. I. Barredo (jose.barredo@jrc.it) the increasing losses from natural disasters to date (Höppe and Pielke Jr., 2006; Schiermeier, 2006). Therefore, failing to adjust for time-variant socio-economic factors yields loss amounts which are not directly comparable over time, but rather results in an ever-growing trend for purely socioeconomic reasons (Rosenzweig et al., 2007). Previous normalisation studies on flood and hurricane damage in the US (Pielke Jr. and Landsea, 1998; Pielke Jr. and Downton, 2000; Pielke Jr. et al., 2008), weather extremes in the US (Changnon et al., 2000; Changnon, 2003), tornadoes in US (Brooks and Doswell, 2001), hurricane losses in the Caribbean region (Pielke Jr. et al., 2003), tropical cyclones in India (Raghavan and Rajesh, 2003) and weather-driven disasters in Australia (Crompton and McAneney, 2008) found no significant trend in losses over time.

The objective of this paper is to present an assessment of normalised flood damage in Europe for the period 19702006. We assessed flood disaster economic losses in $31 \mathrm{Eu}-$ ropean countries. These include the member states of the European Union, Norway, Switzerland, Croatia, and the Former Yugoslav Republic of Macedonia. The paper addresses the question of what the magnitude of economic flood losses over time in Europe would be if the floods from the past would take place under current societal conditions.

Data on flood losses is neither comprehensive nor standardised throughout Europe (Mitchell, 2003). The limitations of global spatial and thematic information on floods over long periods has been often noted (Mitchell, 2003; Peduzzi et al., 2005; Barredo, 2007; Bouwer et al., 2007). Nevertheless, some effort has been made towards the collection of such information. The Emergency Events Database (EMDAT) is one of the main public global databases for natural disasters. It contains core information on several key indicators for natural disasters, including economic damage caused. Another publicly accessible global database on natural disasters is the Natural Hazards Assessment Network (NATHAN) of the reinsurance firm Munich Re. NATHAN

Published by Copernicus Publications on behalf of the European Geosciences Union. 
is a global catalogue of significant natural-disaster economic losses. This study has used available information on flood disasters from the EM-DAT and NATHAN.

When assessing trends in economic flood losses it is important to make a distinction between hydrologic and damaging floods. When climatologists or hydrologists refer to floods, they are usually speaking about hydrologic floods. However, when policy makers use the term floods, they usually refer to flood disasters or damaging floods (Pielke Jr. and Downton, 2000). The difference is that a hydrologic flood occurring in an unpopulated area may cause no damage. Flood disasters are therefore the result of the interaction between hydrologic floods and societal systems. The latter include many subsystems that determine the level of interaction, such as flood mitigation policies and the exposed people and property. This complex situation necessitates the consideration of socio-economic drivers when assessing floodloss trends over long periods (Pielke Jr. and Downton, 2000; Rosenzweig et al., 2007).

Despite the existing evidence (see Table 1) of changes in temperature and precipitation in Europe (Alcamo et al., 2007; Rosenzweig et al., 2007; Trenberth et al., 2007) there is no conclusive evidence for a climate-related trend for hydrologic floods either on a continental or a regional scale in Europe (Glaser and Stangl, 2003; Mudelsee et al., 2003; Lindström and Bergström, 2004; Kundzewicz et al., 2005, 2007; Macklin and Rumsby, 2007). This supports the hypothesis that a positive trend in the increase of flood losses should be attributed to societal shifts in the exposed areas.

The paper is organised in six sections. Section 2 analyses the available data. Section 3 describes the methodology used for normalising flood losses. Section 4 shows the results and assesses the trends of normalised losses. Then the discussion section examines the explanatory drivers of flood losses. This section also considers the limitations of the method and the available data.

\section{Data}

This study addresses direct economic flood losses. A flood is a body of water which rises to overflow land which is not normally submerged (Ward, 1978). Direct economic damage is the tangible economic loss associated with a flood's impact as determined in the weeks and sometimes months after the event. These losses occur after floods as a result of the physical contact of the flood waters with damageable property (Smith and Ward, 1998). Different institutions have developed methods for calculating flood losses in their specific domain. There is no standard procedure to determine a global figure for economic impact, which may lead to different estimates for the same event. Indirect (i.e. secondary and tertiary) and intangible damages (i.e. loss of human life, Illhealth of floods victims), as well as longer-term macroeconomic effects are not considered in this study. These types of impact are the focus of different methodological approaches such as that of Guzzetti et al. (2005).

The data on flood losses were obtained from two public databases for natural disasters. The EM-DAT database of the Centre of Research on Epidemiology of Disasters (CRED) is one of main public global databases for natural disasters, recording information on natural disasters worldwide. Several works related to flood disasters have used EM-DAT as their main source of information (Jonkman, 2005; Peduzzi et al., 2005; Barredo, 2007). The main sources of information of EM-DAT are UN agencies, governmental and nongovernmental organisations, insurance companies, research institutes and press agencies. Several criteria are used by EM-DAT for the inclusion of disasters in the database. A disaster is entered when at least one of the following criteria is fulfilled: a) 10 or more people killed; b) 100 or more people affected/injured/homeless; c) declaration of state of emergency; d) appeal for international assistance. Monetary damage is among the information recorded in EM-DAT.

NATHAN of Munich Re is a publicly accessible global database on natural disasters containing a global catalogue of significant natural-disaster losses. NATHAN includes thematic information on major flood events including casualties and direct economic losses. Records of disasters in NATHAN are based on what Munich Re defines "great natural catastrophes". This is in line with definitions used by the United Nations, where natural catastrophes are considered "great" if the affected region's ability to help themselves is clearly overstretched and supraregional or international assistance is required. This is the case when there are thousands of fatalities, when hundreds of thousands of people are made homeless, or when the economic losses reach exceptional orders of magnitude.

In both databases economic damage is considered as a value of economic losses related to the disaster at the date in which the disaster occurred. Other sources of information were used in this study for verifying the information on flood losses. Those sources are: the Dartmouth Flood Observatory at the University of Dartmouth, archives of on-line news channels, reinsurers (e.g. Swiss Re), national water authorities and the European Union Solidarity Fund (EUSF) records.

The information for this study was accessed in the summer of 2007. We compiled a catalogue with information from EM-DAT and NATHAN. EM-DAT provided information for 114 events registering economic losses between 1970 and 2006. NATHAN accounted for 65 events over the same period. The difference in the number of events reported is due to the fact that NATHAN registers only major events, i.e. "significant disasters". We cross-checked the 65 events reported in NATHAN with those of EM-DAT. Out of 65 events reported in NATHAN 12 events were missing in EM-DAT. For 53 events losses were reported in both databases. In 27 cases there was agreement between the amounts of losses reported and in 26 cases there was disagreement. In these 
Table 1. Summary of available studies on changes in observed climate and flood indicators in Europe.

\begin{tabular}{|c|c|c|}
\hline Source & Variable & Spatial/temporal domain \\
\hline Jones and Moberg (2003) & Annual mean temperature & $\begin{array}{l}\text { Europe has experienced increases over } \\
\text { the 20th century of about } 0.95^{\circ} \mathrm{C} \text {, which is } \\
\text { higher than that of the average global increase. }\end{array}$ \\
\hline Alcamo et al. (2007) & Annual mean temperature & $\begin{array}{l}\text { The warming has been largest over central and } \\
\text { north-eastern Europe and in mountainous regions, } \\
\text { with lower increases in Mediterranean regions. }\end{array}$ \\
\hline $\begin{array}{l}\text { Klein Tank et al. (2002), } \\
\text { Klein Tank and Können (2003), } \\
\text { Alcamo et al. (2007) }\end{array}$ & Winter precipitation & $\begin{array}{l}\text { There is evidence of an increase in most } \\
\text { of the Atlantic and northern parts of Europe } \\
\text { during the second half of the 20th century, with } \\
\text { a general decrease southward to the Mediterranean. }\end{array}$ \\
\hline Moberg et al. $(2005,2006)$ & Winter precipitation & $\begin{array}{l}\text { Winter precipitation totals in central Europe have } \\
\text { increased significantly by } \sim 12 \% \text { over the last } \\
100 \text { years. The increases in average precipitation } \\
\text { trends for summers were smaller, being about } 1 \% \text {. }\end{array}$ \\
\hline Kundzewicz et al. (2006) & Autumn and winter precipitation & $\begin{array}{l}\text { It was observed a pronounced increase in autumn and } \\
\text { winter precipitation in the latter part of the 20th } \\
\text { century over northern Europe and western Russia. }\end{array}$ \\
\hline $\begin{array}{l}\text { Frich et al. (2002), } \\
\text { Klein Tank et al. (2002), } \\
\text { Klein Tank and Können (2003), } \\
\text { Haylock and Goodess (2004), } \\
\text { Alexander et al. (2006) }\end{array}$ & Mean precipitation per wet day & $\begin{array}{l}\text { There is recent evidence of an increase in most parts } \\
\text { of Europe, even in some areas which are becoming drier. }\end{array}$ \\
\hline Moberg et al. (2006) & Mean precipitation per wet day & $\begin{array}{l}\text { Winters in central and western Europe have experienced } \\
\text { an increase in both the frequency of precipitation events } \\
\text { and in the average precipitation per wet day. }\end{array}$ \\
\hline Haylock et al. (2004) & Extreme precipitation events & $\begin{array}{l}\text { For winter it was found a change to wetter conditions } \\
\text { and more extreme precipitation events in north and } \\
\text { central Europe and dryer conditions in the south, with } \\
\text { a slight increase in the occurrence of extreme events. }\end{array}$ \\
\hline $\begin{array}{l}\text { Glaser and Stangl (2003), } \\
\text { Mudelsee et al. (2003), } \\
\text { Lindström and Bergström (2004), } \\
\text { Kundzewicz et al. (2005), } \\
\text { Macklin and Rumsby (2007) }\end{array}$ & Extreme river flows & $\begin{array}{l}\text { In Europe there is no conclusive evidence for a climate- } \\
\text {-related trend for floods. No homogeneous trend in } \\
\text { extreme river flows is apparent, either on a continental } \\
\text { or a regional scale (i.e. Dutch Rhine Delta, Central } \\
\text { Europe, Sweden and British uplands). }\end{array}$ \\
\hline
\end{tabular}

26 cases we used the information on economic losses from NATHAN since it is considered to be a more accurate source for economic losses.

Four events were eliminated from the original 114 records in EM-DAT because they actually concerned windstorms that were recorded as floods. The resulting catalogue contains 122 flood events. The ancillary sources of information were useful for verifying aspects such as affected countries or date of occurrence. EM-DAT and NATHAN report losses in US dollars (US\$) (not corrected for inflation). US\$ has been used as currency in this study because exchange rates are not available before the introduction of the Euro.
Records of natural-disaster losses from earlier years are usually affected by gaps. The effect of improvements in data collection and flows of information could induce biased trends about disaster losses (Berz, 2000). A simple assessment of the number of damaging events included in the catalogue reveals that in the first half of the assessment (19701988) there were 32 events, whereas in the period 1989-2006 there were 90 . This difference goes reasonably beyond natural variability or societal changes and can therefore be attributed to inaccuracies in the accounting of the events. The figures of losses reported are also prone to a degree of uncertainty. The fact that the cross-checking of EM-DAT and NATHAN reveals differences in 26 out of 53 matching events 
supports this assumption. A method for dealing with these sources of uncertainty is to assess only the losses produced by major disasters. They are usually better recorded and can be investigated decades after their occurrence (Berz, 2000; Muir Wood et al., 2006). This is the approach followed in this study. Therefore, only events that can be considered as major events, i.e. those with economic losses above a given threshold, have been included in the trend analysis.

\section{Methods}

In the field of natural hazards the term normalisation is used to describe the process of eliminating the socio-economic influence of the growing exposure in disaster areas. The purpose of normalising historical loss records is to produce values that are more representative in today's context (Changnon et al., 1997; Pielke Jr. and Landsea, 1998; Pielke Jr. et al., 2008). Previous studies have considered population, inflation and wealth as factors for normalisation (Pielke Jr. and Landsea, 1998). However, given that information accounting for the changes in wealth in exposed areas is usually unavailable, it becomes necessary to use proxies for measuring their influence (Changnon et al., 1997; Changnon and Changnon, 1998; Pielke Jr. and Landsea, 1998; Pielke Jr. and Downton, 2000; Changnon, 2003; Crompton and McAneney, 2008; Pielke Jr. et al., 2008). Pielke and Landsea (1998) implemented a normalisation method for hurricane damage by using factors such as changes in population, inflation and real per capita wealth. Crompton and McAneney (2008), on the other hand, normalised losses from meteorological hazards using two surrogate factors, namely changes in both the number and the average nominal value of dwellings over time. The effect of inflation was implicitly calculated.

Munich Re (1999) evaluated the increase in nominal values of exposed assets in catastrophe regions in Germany and the US making a differentiation between the portion of the nominal increase in values caused by inflation and the portion due to the rise in the standard of living. For the second factor, the study showed that Gross Domestic Product (GDP) can be taken as a surrogate measure for describing the development of values in exposed areas. Despite many differences in political and economic trends in the two countries there is sufficient parity between the increase in exposed assets and GDP to permit the utilisation of GDP as an approximate indicator of the net increase in values.

We envisage four factors for normalising flood losses at the continental scale. In order to make the data on losses comparable over time it is necessary to adjust the original data for inflation, inter-country price differences, population and per capita wealth at the country level. This study uses population and real $\mathrm{GDP}^{1}$ per capita in the country of the

\footnotetext{
${ }^{1}$ Gross domestic product (GDP) is an aggregate measure of production equal to the sum of the gross values added of all resident institutional units engaged in production. The sum of the final uses
}

flood event as a measure of the changes in exposure over time. Hereby it is assumed that the overall trends of both factors at country level represent those of the flood-risk areas. Time-series data on GDP and population were obtained from the Statistical Databases of United Nations Statistics Division and EUROSTAT.

Differences in prices levels can be important in countries with different socio-economic conditions. We use purchasing power parities (PPP) to eliminate price level differences across countries. PPP are formally defined as the rates of currency conversion that equalise the purchasing power of different currencies by eliminating the differences in price levels between countries. In their simplest form, PPP are price relatives that reflect the ratio of the prices of the same good or service in different countries (OECD-EUROSTAT, 2006). PPP tell us how many currency units a given quantity of goods and services will cost in different countries. It is recognised that the effect of differences in price levels between countries with different socio-economic conditions is best captured by using PPP (Schreyer and Koechlin, 2002; Höppe and Pielke Jr., 2006; Van Vuuren and Alfsen, 2006; Fisher et al., 2007; Nicholls et al., 2008). Values expressed in PPP are considered as standardised values and are recognised as a good indicator for inter-country comparison in the natural risks field (Nicholls et al., 2008). Time-series data on PPP were obtained from the Total Economy Database of the Conference Board and Groningen Growth and Development Centre (2007). For example, a flood disaster that occurred in 2006 in Germany producing EUR 100 million in nominal damage cannot be compared with a flood that occurred in Greece during the same year and having the same nominal damage of EUR 100 million. Adjusting the losses by using PPP reveals that the flood in Germany and Greece would represent respectively 95 and 119 million in international EUR of 2006 using PPP. In this example the PPP ratio for Germany is 1.050 , for Greece 0.838 , and the reference (1.00) represents the overall 27 member states of the European Union (data from Eurostat).

Thus the normalisation equation is defined as follows:

$L_{2006}=L_{i} \times I_{i j} \times \mathrm{PPP}_{i j} \times P_{i j} \times W_{i j}$

The equation converts nominal losses in the year of occurrence of the event $\left(L_{i}\right)$ to normalised losses in $2006\left(L_{2006}\right)$ expressed in international US\$ using PPP (this is the unit for monetary amounts of normalised losses in this study).

Where $j$ is the country affected by the event; $I_{i j}$ is the inflation factor to 2006 values for year $i$ in country $j$; $\mathrm{PPP}_{i j}$ is the purchasing power parity factor for year $i$ in country $j$; $P_{i j}$ is the population factor defined as the ratio of the number of inhabitants in 2006 in country $j$ to the number in year $i$;

of goods and services measured in purchasers' prices, less the value of imports of goods and services, or the sum of primary incomes distributed by resident producer units (United Nations Statistics Division, on-line glossary). 
$W_{i j}$ is the wealth factor defined as the ratio of the real GDP per capita in 2006 in country $j$ to the value in year $i$.

\section{Results}

To minimize the effect of better accounting of flood losses in recent decades this study considers only major floods, i.e. those with losses larger than 1000 million in 2006 US\$ normalised values. Based on this criterion, 27 out of 122 events of the catalogue were classified as major disasters. It is interesting that during the study period $82 \%$ of the losses were produced by major floods, representing only $22 \%$ of the overall number of events. In the first half of the assessment (1970-1988) there were 12 major events, and in the period 1989-2006 there were 15. The difference in the number of floods in the two periods can reasonably be consequence of natural variability. We assume that the effect of incompleteness of the original data is considerably reduced in the dataset of 27 major floods.

Expressed in 2006 US\$ normalised values, total flood losses over the 1970-2006 period amounted to 140 billion, with an average annual flood loss of 3.8 billion. Figure 1 shows the annual distribution of the original (raw) flood losses in current US\$ (not corrected for inflation). The information in Fig. 1 must be viewed cautiously, because that series includes shifts due to societal changes. Figure 2 shows the normalised annual distribution of flood losses. The year of maximum losses is 1983, followed by 2002 and 1997 . The time series shows no evident trend over time, although that there seems to be an increased frequency of years having large losses from 1994 to 2002. Nevertheless, in the four last years of the assessment period annual losses are below the annual average losses. Figure 3 shows the 5 -year moving average of normalised losses. This figure does not reveal a clear trend over time. Rather, a sequence of alternating periods with losses below and over the annual average can be observed. This could be attributed to natural variability of extreme floods.

These results indicate that changes in population, inflation and per capita real wealth are the main factors contributing to the increase of the original raw losses. After filtering their influence there remains no evident signal suggesting any influence of anthropogenic climate change on the trend of flood losses in Europe during the assessed period.

\section{Discussion}

This study showed that there is no evidence of a clear positive trend in normalised flood losses in Europe. In a hypothetical scenario without climate change, flood losses would continue to increase as a consequence of societal and economic factors. Normalisation eliminates the influence of changes in exposure to floods and reveals that most of the increase

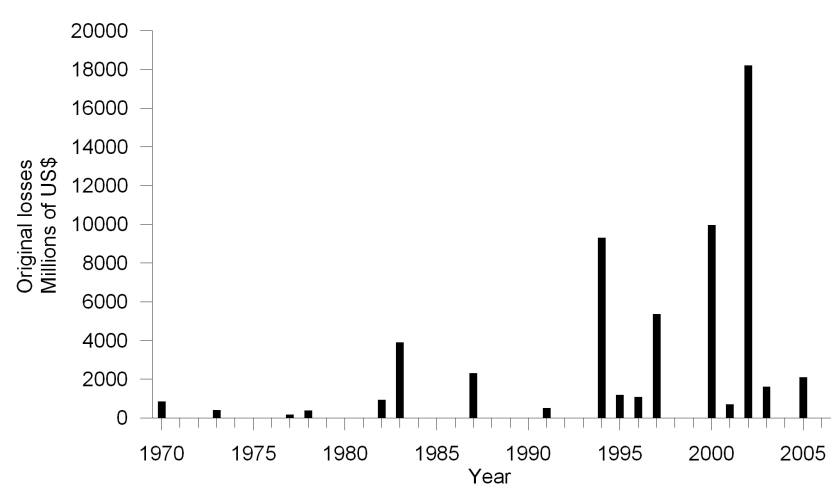

Fig. 1. Original annual flood losses in Europe from major flood disasters as reported in the EM-DAT and NATHAN (not corrected for inflation). The information in this figure must be viewed cautiously because it includes shifts due to changes in inflation, wealth and exposure.

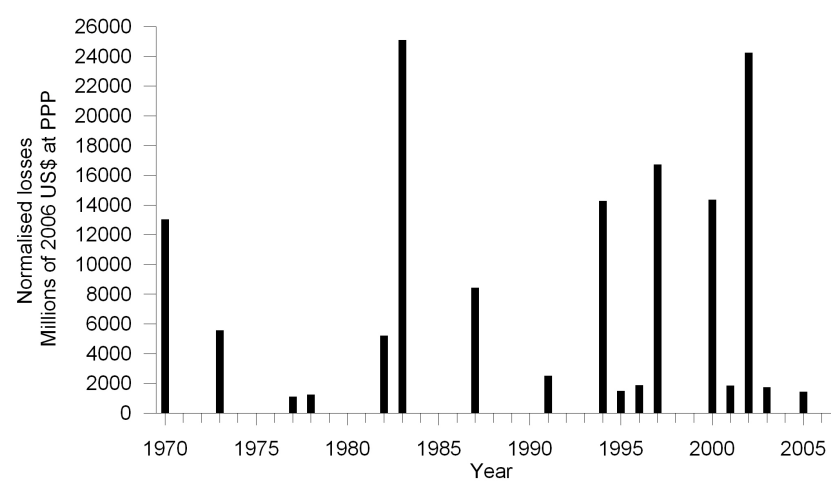

Fig. 2. Annual flood losses in Europe from major flood disasters normalised to 2006 values.

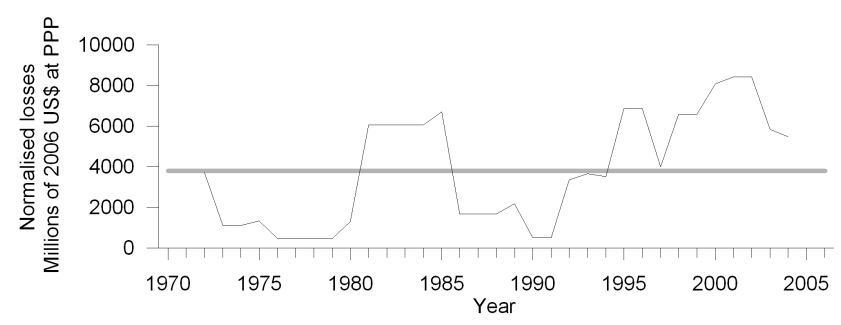

Fig. 3. 5-year moving average of annual flood losses in Europe from major flood disasters normalised to 2006 values. The grey line represents the average annual flood losses of the overall period. 
observed in the original nominal flood losses is due to socioeconomic shifts. Since the 1970s Europe has registered an increasing standard of living, real per capita wealth and population. As a consequence, exposure of people and assets in flood-prone areas has been ever growing. Nevertheless, also natural variability may have played a role in the loss trends. It may have an influence in the frequency of floods over time. In addition based on the latest climate predictions for the coming decades (Dankers and Feyen, 2008), climate change may very likely result in an increase of flood losses in Europe.

It is worth noting that potential effects of human alterations in river basins have not been taken into account. Rather, this study assumed constant flood mitigation through time. In regions where relevant flood mitigation measures have been implemented during the period studied any changes in the frequency of extreme floods may have been offset by the measures adopted. Considering the effects of flood-protection measures, however, is a complex issue because accurate data on measures such as investment in flood protection is not available in a standardised format at continental level.

Another limitation is the completeness of and the degree of uncertainty in the original flood losses records used in this study. The available information on losses from natural disasters in Europe can produce biased trends if not properly filtered. There is a higher frequency in the number of minor events documented in recent years than in the first years of the assessment. Using only major disasters for the assessment of trends assures more reliable results. It is difficult to assess the uncertainty related with the reported losses since no other public accurate data exists for verifying any biases in the data. It is therefore essential to improve data collection and to maintain an open-source peer-reviewed database that would enable scientists to study time series of disaster losses (Bouwer et al., 2007). Policies, economic decisions and mitigation activities should be supported by long-term, accurate data and assessments. Monitoring of natural-disaster losses should be a priority for the years to come in order to produce updated information about the evolution of trends in flood losses.

The continental scope of this study might introduce uncertainty in many aspects. Results of simple-country analyses are less uncertain than those of a multi-county approach. For example, changes in building standards for flood protection may arise between countries at different times. This may influence aggregate losses at the continental level. The fact that countries typically impose different flood protection standards may also impact aggregated losses.

Notwithstanding these limitations, the methodology of this study provides an effective approach for normalising flood losses. Furthermore, using PPP for integrating data on losses from several countries is a novel aspect of this study.

Policy makers should not expect an unequivocal answer to questions concerning the linkage between flood-disaster losses and anthropogenic climate change, as this field will very likely remain an important area of research for years to come (Höppe and Pielke Jr., 2006). Longer time-series of losses are necessary for more conclusive results. Policy making in the field of natural disasters should be supported by long-term accurate data and assessments. However, current records of disaster losses are generally of poor quality (Bouwer et al., 2007), which may introduce significant bias in the resulting trends. The monitoring of losses from floods and other weather-driven disasters should therefore become a priority over the coming years in order to produce updated information about the role of human-induced climate change in the trends regarding disaster losses.

Acknowledgements. I would like to thank three anonymous referees for their helpful suggestions and Luc Feyen for his advice during the editing of the manuscript. The views expressed are purely those of the writer and may not in any circumstance be regarded as stating an official position of the European Commission.

Edited by: F. Guzzetti

Reviewed by: three anonymous referees

\section{References}

Alcamo, J., Moreno, J. M., Nováky, B., Bindi, M., Corobov, R., Devoy, R. J. N., Giannakopoulos, C., Martin, E., Olesen, J. E., and Shvidenko, A.: Europe. Climate Change 2007: Impacts, Adaptation and Vulnerability, in: Contribution of Working Group II to the Fourth Assessment Report of the Intergovernmental Panel on Climate Change, edited by: Parry, M. L., Canziani, O. F., Palutikof, J. P., van der Linden, P. J., and Hanson, C. E., Cambridge University Press, Cambridge, UK, 541-580, 2007.

Alexander, L. V., Zhang, X., Peterson, T. C., Caesar, J., Gleason, B., Tank, K., Haylock, M., Collins, D., Trewin, B., Rahimzadeh, F., Tagipour, A., Kumar, R., Revadekar, J., Griffiths, G., Vincent, L., Stephenson, D. B., Burn, J., Aguilar, E., Brunet, M., Taylor, M., New, M., Zhai, P., Rusticucci, M., and Vazquez-Aguirre, J. L.: Global observed changes in daily climate extremes of temperature and precipitation, J. Geophys. Res., 111, D05109, doi:10.1029/2005JD006290, 2006.

Barredo, J. I.: Major flood disasters in Europe: 1950-2005, Nat. Hazards, 42, 125-148, 2007.

Berz, G.: Flood disasters: lessons from the past-worries for the future, P. I. Civil Eng., 142, 3-8, 2000.

Bouwer, L. M., Crompton, R. P., Faust, E., Hoppe, P., and Pielke Jr., R. A.: Disaster Management: Confronting Disaster Losses, Science, 318, 753 pp., 2007.

Brooks, H. E. and Doswell, C. A.: Normalized Damage from Major Tornadoes in the United States: 1890-1999, Weather Forecast., 16, 168-176, 2001.

Changnon, D. and Changnon, S. A.: Evaluation of Weather Catastrophe Data for Use in Climate Change Investigations, Climatic Change, 38, 435-445, 1998.

Changnon, S. A., Changnon, D., Fosse, E. R., Hoganson, D. C., Roth, R. J., and Totsch, J. M.: Effects of Recent Weather Extremes on the Insurance Industry: Major Implications for the Atmospheric Sciences, B. Am. Meteorol. Soc., 78, 425-435, 1997. 
Changnon, S. A., Pielke, R. A., Changnon, D., Sylves, R. T., and Pulwarty, R.: Human Factors Explain the Increased Losses from Weather and Climate Extremes, B. Am. Meteorol. Soc., 81, 437442, 2000

Changnon, S. A.: Shifting Economic Impacts from Weather Extremes in the United States: A Result of Societal Changes, Not Global Warming, Nat. Hazards, 29, 273-290, 2003.

Crompton, R. P. and McAneney, K. J.: Normalised Australian insured losses from meteorological hazards: 1967-2006, Environ. Sci. Policy, 11, 371-378, 2008.

Dankers, R. and Feyen, L.: Climate change impact on flood hazard in Europe: An assessment based on highresolution climate simulations, J. Geophys. Res., 113, D19105, doi:10.1029/2007JD009719, 2008.

Fisher, B. S., Nakicenovic, N., Alfsen, K., Corfee Morlot, J., de la Chesnaye, F., Hourcade, J.-C., Jiang, K., Kainuma, M., La Rovere, E., Matysek, A., Rana, A., Riahi, K., Richels, R., Rose, S., van Vuuren, D., and Warren, R.: Issues related to mitigation in the long term context, in: Climate Change 2007: Mitigation, Contribution of Working Group III to the Fourth Assessment Report of the Inter-governmental Panel on Climate Change, edited by: Metz, B., Davidson, O. R., Bosch, P. R., Dave, R., and Meyer, L. A., Cambridge University Press, Cambridge, 169-250, 2007.

Frich, P., Alexander, L. V., Della-Marta, P., Gleason, B., Haylock, M., Klein Tank, A. M. G., and Peterson, T.: Observed coherent changes in climatic extremes during the second half of the twentieth century, Climate Res., 19, 193-212, 2002.

Glaser, R. and Stangl, H.: Historical floods in the Dutch Rhine Delta, Nat. Hazards Earth Syst. Sci., 3, 605-613, 2003, http://www.nat-hazards-earth-syst-sci.net/3/605/2003/.

Guzzetti, F., Stark, C. P., and Salvati, P.: Evaluation of flood and landslide risk to the population of Italy, Environ. Manage., 36, 15-36, 2005.

Haylock, M. R. and Goodess, C. M.: Interannual variability of European extreme winter rainfall and links with mean large-scale circulation, Int. J. Climatol., 24, 759-776, 2004.

Höppe, P. and Pielke Jr., R. A.: Workshop Summary Report, in: Workshop on Climate Change and Disaster Losses: Understanding and Attributing Trends and Projections, edited by: Höppe, P. and Pielke Jr., R. A., Hohenkammer, Germany, 4-12, 2006.

Jones, P. D. and Moberg, A.: Hemispheric and Large-Scale Surface Air Temperature Variations: An Extensive Revision and an Update to 2001, J. Climate, 16, 206-223, 2003.

Jonkman, S. N.: Global Perspectives on Loss of Human Life Caused by Floods, Nat. Hazards, 34, 151-175, 2005.

Klein Tank, A. M. G., Wijngaard, J. B., Können, G. P., Böhm, R., Demarée, G., Gocheva, A., Mileta, M., Pashiardis, S., Hejkrlik, L., Kern-Hansen, C., Heino, R., Bessemoulin, P., MüllerWestermeier, G., Tzanakou, M., Szalai, S., Pálsdóttir, T., Fitzgerald, D., Rubin, S., Capaldo, M., Maugeri, M., Leitass, A., Bukantis, A., Aberfeld, R., van Engelen, A. F. V., Forland, E., Mietus, M., Coelho, F., Mares, C., Razuvaev, V., Nieplova, E., Cegnar, T., Antonio López, J., Dahlström, B., Moberg, A., Kirchhofer, W., Ceylan, A., Pachaliuk, O., Alexander, L. V., and Petrovic, P.: Daily dataset of 20th-century surface air temperature and precipitation series for the European Climate Assessment, Int. J. Climatol., 22, 1441-1453, 2002.

Klein Tank, A. M. G. and Können, G. P.: Trends in Indices of Daily
Temperature and Precipitation Extremes in Europe, 1946-99, J. Climate, 16, 3665-3680, 2003.

Kundzewicz, Z. W., Graczyk, D., Maurer, T., Piskwar, I., Radziejewski, M., Svensson, C., and Szwed, M.: Trend detection in river flow series: 1. Annual maximum flow, Hydrolog. Sci. J., 50, 797-810, 2005.

Kundzewicz, Z. W., Radziejewski, M., and Pinskwar, I.: Precipitation extremes in the changing climate of Europe, Climate Res., 31, 51-58, 2006.

Kundzewicz, Z. W., Mata, L. J., Arnell, N. W., Döll, P., Kabat, P., Jiménez, B., Miller, K. A., Oki, T., Sen, Z., and Shiklomanov, I. A.: Freshwater resources and their management. Climate Change 2007, in: Impacts, Adaptation and Vulnerability, Contribution of Working Group II to the Fourth Assessment Report of the Intergovernmental Panel on Climate Change, edited by: Parry, M. L., Canziani, O. F., Palutikof, J. P., van der Linden, P. J., and Hanson, C. E., Cambridge University Press, Cambridge, UK, 173-210, 2007.

Lindström, G. and Bergström, S.: Runoff trends in Sweden 1807 2002, Hydrolog. Sci. J., 49, 69-83, 2004.

Macklin, M. G. and Rumsby, B. T.: Changing climate and extreme floods in the British uplands, T. I. Brit. Geogr., 32, 168-186, 2007.

Mitchell, J. K.: European River Floods in a Changing World, Risk Anal., 23, 567-574, 2003.

Moberg, A. and Jones, P. D.: Trends in indices for extremes in daily temperature and precipitation in central and western Europe, 1901-99, Int. J. Climatol., 25, 1149-1171, 2005.

Moberg, A., Jones, P. D., Lister, D., Walther, A., Brunet, M., Jacobeit, J., Alexander, L. V., Della-Marta, P. M., Luterbacher, J., Yiou, P., Chen, D., Klein Tank, A. M. G., Saladie, O., Sigro, J., Aguilar, E., Alexandersson, H., Almarza, C., Auer, I., Barriendos, M., Bergert, M., Bergstrom, H., Bohm, R., Butler, J., Caesar, J., Drebs, A., Founda, D., Gerstengarbe, F.-W., Micela, G., Maugeri, M., Osterle, H., Panzic, K., Petrakis, M., Srnec, L., Tolasz, R., Tuomenvirta, H., Werner, P. C., Linderholm, H., Philipp, A., Wanner, H., and Xoplaki, E.: Indices for daily temperature and precipitation extremes in Europe analysed for the period 1901-2000, J. Geophys. Res., 111, D22106, doi:10.1029/2006JD007103, 2006.

Mudelsee, M., Borngen, M., Tetzlaff, G., and Grunewald, U.: No upward trends in the occurrence of extreme floods in central Europe, Nature, 425, 166-169, 2003.

Muir Wood, R., Miller, S., and Boissonnade, A.: The search for trends in a global catalogue of normalized weather-related catastrophe losses, in: Workshop on Climate Change and Disaster Losses - Understanding and Attributing Trends and Projections, edited by: Höppe, P., and Pielke Jr., R. A., Hohenkammer, Germany, 188-194, 2006.

Munich Re: Topics 2000: Natural catastrophes - the current position, Munich-Re-Munich Reinsurance Company, Munich, TOPICS, 126 pp., 1999.

Nicholls, R. J., Hanson, S., Herweijer, C., Patmore, N., Hallegatte, S., Corfee-Morlot, J., Château, J., and Muir-Wood, R.: Ranking port cities with high exposure and vulnerability to climate extremes - Exposure estimates, Organisation for Economic Cooperation and Development, Paris, Environment working papers, 1, 62 pp., 2008.

OECD-EUROSTAT: EUROSTAT-OECD Methodological Manual 
on Purchasing Power Parities, OECD, Paris, Statistics, 267 pp., 2006.

Peduzzi, P., Herold, H., and Dao, C.: Mapping Disastrous Natural Hazards Using Global Datasets, Nat. Hazards, 35, 265-289, 2005.

Pielke Jr., R. A. and Landsea, C. W.: Normalized Hurricane Damages in the United States: 1925-95, Weather Forecast., 13, 621631, 1998.

Pielke Jr., R. A. and Downton, M. W.: Precipitation and Damaging Floods: Trends in the United States, 1932-97, J. Climate, 13, 3625-3637, 2000.

Pielke Jr., R. A., Rubiera, J., Landsea, C., Fernandez, M. L., and Klein, R.: Hurricane Vulnerability in Latin America and The Caribbean: Normalized Damage and Loss Potentials, Natural Hazards Review, 4, 101-114, 2003.

Pielke Jr., R. A., Gratz, J., Landsea, C. W., Collins, D., Saunders, M. A., and Musulin, R.: Normalized Hurricane Damage in the United States: 1900-2005, Natural Hazards Review, 31, 29-42, 2008.

Raghavan, S. and Rajesh, S.: Trends in Tropical Cyclone Impact: A Study in Andhra Pradesh, India, B. Am. Meteorol. Soc., 84, 635-644, 2003.

Rosenzweig, C., Casassa, G., Karoly, D. J., Imeson, A., Liu, C., Menzel, A., Rawlins, S., Root, T. L., Seguin, B., and Tryjanowski, P.: Assessment of observed changes and responses in natural and managed systems, in: Climate Change 2007: Impacts, Adaptation and Vulnerability, Contribution of Working Group II to the Fourth Assessment Report of the Intergovernmental Panel on Climate Change, edited by: Parry, M. L., Canziani, O. F., Palutikof, J. P., van der Linden, P. J., and Hanson, C. E., Cambridge University Press, Cambridge, UK, 79-131, 2007.
Schiermeier, Q.: Insurers' disaster files suggest climate is culprit, Nature, 441, 674-675, 2006.

Schreyer, P. and Koechlin, F.: Purchasing power parities - measurement and uses, Organisation for Economic Co-operation and Development, Paris, OECD Statistics Brief, 3, 8 pp., 2002.

Smith, K. and Ward, R.: Floods - Physical Processes and Human Impacts, John Wiley \& Sons, Chichester, 382 pp., 1998.

The Conference Board and Groningen Growth and Development Centre: Total Economy Database The Conference Board and Groningen Growth and Development Centre, available at: http: //www.conference-board.org/economics, 2007.

Trenberth, K. E., Jones, P. D., Ambenje, P., Bojariu, R., Easterling, D., Klein Tank, A., Parker, D., Rahimzadeh, F., Renwick, J. A., Rusticucci, M., Soden, B., and Zhai, P.: Observations: Surface and Atmospheric Climate Change, in: Climate Change 2007: The Physical Science Basis. Contribution of Working Group I to the Fourth Assessment Report of the Intergovernmental Panel on Climate Change, edited by: Solomon, S., Qin, D., Manning, M., Chen, Z., Marquis, M., Averyt, K. B., Tignor, M., and Miller, H. L., Cambridge University Press, Cambridge, UK, 235-336, 2007.

Van Vuuren, D. P. and Alfsen, K. H.: PPP Versus MER: searching for answers in a multi-dimensional debate, Climatic Change, 75, 47-57, 2006.

Ward, R. C.: Floods: A Geographical Perspective, Macmillan, London, 244 pp., 1978. 